\title{
MEMBANGUN KEMAMPUAN SPASIAL LEWAT PELATIHAN PEMETAAN DIGITAL BERBASIS SISTEM INFORMASI GEOGRAFIS UNTUK APARATUR DESA
}

\section{SPATIAL BUILDING LEVEL BY DIGITAL MAPPING TRAINING BASED ON GEOGRAPHIC INFORMATION SYSTEM FOR THE VILLAGE APPARATUS}

\author{
${ }^{1)}$ Dhi Bramasta, ${ }^{2}$ Anang Widhi Nirwansyah \\ ${ }^{1)}$ Program Studi Pendidikan Guru Sekolah Dasar, ${ }^{2}$ Program Studi Pendidkan Geografi, FKIP, \\ Universitas Muhammadiyah Purwokerto \\ Jl. Raya Dukuh Waluh PO BOX 202 Purwokerto 53182 \\ Telepon: (0281)636751 Ext : 130 Fax (0281)637239 \\ email : dhibramasta@ump.ac.id
}

\begin{abstract}
ABSTRAK
Peningkatan keahlian pemetaan dasar bagi aparatur desa sangat penting dalam takaran perencanaan tata ruang sudah merupakan alat pemerintahan baku yang dibuat secara berkala pada tingkat nasional, propinsi, kabupaten dan bahkan desa, akan tetapi alat ini seringkali kehilangan makna dan fungsinya dikarenakan oleh pendekatan dan proses pembuatannya yang tidak tepat. Hal ini banyak disebabkan oleh kurangnya kapasitas maupun keterampilan sumber daya manusianya, dan skill pemetaan yang belum dikuasai oleh aparat pemerintah di level dasar termasuk pada level kelurahan dan kecamatan. Kegiatan program IbM ini bertujuan memberikan pelatihan pada perangkat desa di Kelurahan Kembaran Kecamatan Kembaran Kabupaten Banyumas untuk meningkatkan kapasitas dan keterampilan perangkat desa dalam membuat peta digital yang benar,sehingga perangkat desa bisa melakukan pemetaan administratif wilayahnya dengan memanfaatkan teknologi Sistem informasi geografiss serta dapat menyediakan kebutuhan masyarakat akan peta, guna mendukung kegiatan akademik dan perencanaan pada level diatasnya.Metode dalam kegiatan ini adalah ceramah, diskusi dan praktek aplikasi pembuatan peta dengan SIG menggunakan software Arcview. Hasil pelatihan berupa peningkatan kapasitas dan keterampilan perangkat desa dalam membuat peta, peta administrasi dan penggunaan lahan Kelurahan Kembaran Kecamatan Kembaran Kabupaten Banyumas dengan aplikasi SIG. Disamping itu perangkat desa juga diajarkan cara megaplikasikan GPS, karena peta yang dihasilkan dari pelatihan ini merupakan peta administrasi desa dengan penentuan batas dilakukan dengan memanfaatkan teknologi survey GPS dan data penginderaan jauh resolusi tinggi.
\end{abstract}

Kata Kunci :Kemampuan Spasial, Pemetaan Digital, Sistem Informasi Geografis

\section{ABSTRACT}

Basic skills mapping improvement for rural apparatus is crucial in spatial planning duties as a means of standardized governance made at the national, provincial, district and even village levels, but this tool often loses its meaning and functioning due to its approach and manufacturing process not exactly. This is largely due to the lack of human resources capacity and skills, and mapping skills not yet controlled by government officials at the basic level including at the sub-district and sub-district levels.This IbM program aims to provide training on village apparatus in Kembaran Village Kembaran Sub-district of Banyumas Regency to improve the capacity and skills of village apparatus in making correct digital maps. So the village apparatus can do the administrative mapping of its territory by utilizing Geographic Information System technology and can provide the community's need for maps, in order to support academic and planning activities on the upper levels. Methods in this activity are lectures, discussions and practice of map making application with SIG using Arcview software. The results of the training in the form of capacity building and skills of village officials in making maps, 
Dhi Bramasta, Anang Widhi Nirwansyah

administrative maps and land use Kembaran Village Kembaran District Banyumas District with GIS applications. Besides, the village apparatus is also taught how to apply GPS, because the map produced from this training is a village administration map with boundary determination done by utilizing Global Positiioning System survey technology and high resolution remote sensing data.

Keywords : Spatial Capabilities, Digital Mapping, Geographic Information System

\section{PENDAHULUAN}

Perencanaan tata ruang sudah merupakan alat pemerintahan baku yang dibuat secara berkala pada tingkat Nasional, Propinsi, Kabupaten dan bahkan Desa, akan tetapi alat ini seringkali kehilangan makna dan fungsinya dikarenakan oleh pendekatan dan proses pembuatannya yang tidak tepat. Hal ini banyak disebabkan oleh kurangnya kapasitas maupun keterampilan sumber daya manusianya, dan skill pemetaan yang belum dikuasai oleh aparat pemerintah di level dasar termasuk pada level kelurahan dan kecamatan. Perlu disajikan informasi geospasial menggunakan peta dan disosialisasikan dari level tertinggi pemerintahan sampai pada tingkat terendah desa/kelurahan.

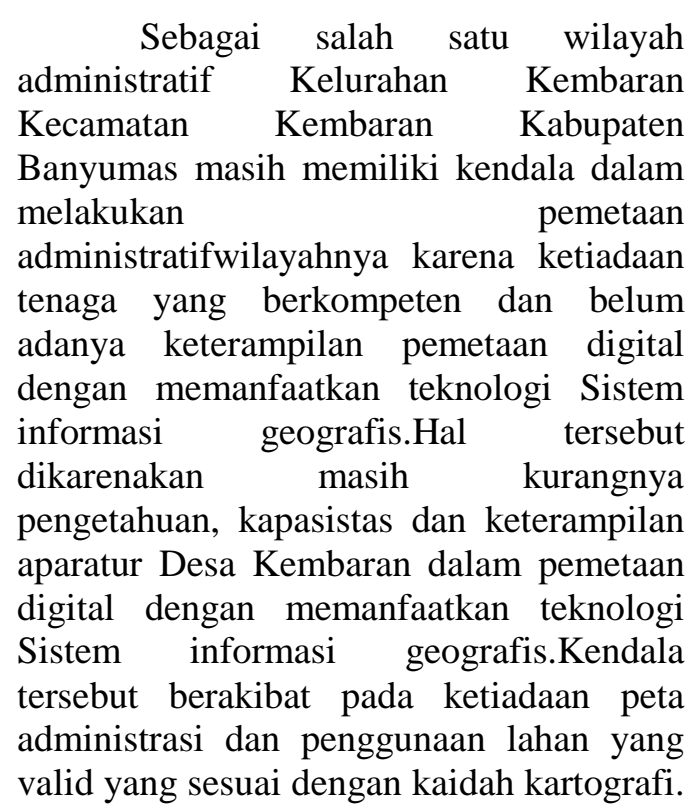

Disisi lain kebutuhan masyarakat terhadap peta ini sangat vital guna mendukung kegiatan akademik dan perencanaan pada level diatasnya. Pemerintah desa memerlukan adanya suatu sistem basis data yang memadai.Hal ini meliputi pengetahuan lokal maupun formal mengenai penghidupan masyarakat, fungsi biofisik dan sumber daya manusia.Datadata seperti batas administratif, tata guna lahan, jalan, sungai serta distribusi penduduk dalam bentuk grafik perlu diperlukan sebagai data dasar bagi pemerintah di level desa. Penguasaan kemampuan dasar pemetaan menggunakan Sistem informasi geografis dalam hal ini perlu dikembangkan pada aparatur desa sebagai penyedia informasi dasar pada level pemerintahan terendah. Optimalisasi peran aparatur desa sebagai pengembang informasi spasial ini tentu akan memberikan dukungan pada pemerintahan diatasnya baik pada level kecamatan ataupun kabupaten.

Pemanfaatan pemetaan digital dengan teknologi Sistem informasi geografistelah banyak dimanfaatkan dalam penelitian dan pengembangan wilayah yang dilakukan dan dikaji mengenai bencana oleh Nirwansyah (2012) dan Bramasta (2014) mengenai proses keruangan pelestarian Saujana Budaya Kota (Urban Heritage) di Kecamatan Laweyan Kota Surakarta merupakan contoh pemanfaatan teknologi Sistem informasi geografis yang muaranya pada rekomendasi pemerintah dalam memanfaatkan teknologi geospasial pada 
berbagai kegiatan perencanaan.

Pengetahuan, kapasitas dan keterampilan pemetaan digital dengan memanfaatkan teknologi Sistem informasi geografis aparatur desa mutlak diperlukan, sehingga pengabdian pada masyarakat ini bertujuan untuk memberikan pelatihan pada perangkat desa di Kelurahan Kembaran Kecamatan Kembaran Kabupaten Banyumas untuk meningkatkan kapasitas dan keterampilan perangkat desa dalam membuat peta digital yang sesuai dengan kaidah kartografi yang benar. Sehingga perangkat desa bisa melakukan pemetaan administratif wilayahnya dengan memanfaatkan teknologi Sistem informasi geografis serta dapat menyediakan kebutuhan masyarakat akan peta, guna mendukung kegiatan akademik dan perencanaan pada level diatasnya.

\section{METODE}

Pelaksanaan pelatihan dilakukan secara klasikal dengan mengutamakan pengembangan pengetahuan dasar mengenai pemetaan, kartografi, dan Sistem informasi geografis. Pengembangan keahlian penggunaan perangkat lunak SIG ArcView GIS 3.3 dilakukan dengan pelatihan terbimbing dengan modul pelatihan yang telah disiapkan. Peserta pelatihan yakni perangkat Desa Kembaran yang telah ditetapkan oleh Kepala Desa berjumlah 7 orang. Skema pelatihan pemetaan digital dasar untuk aparatur Desa Kembaran dilaksanakan secara runtut seperti terlihat pada gambar 1 berikut :

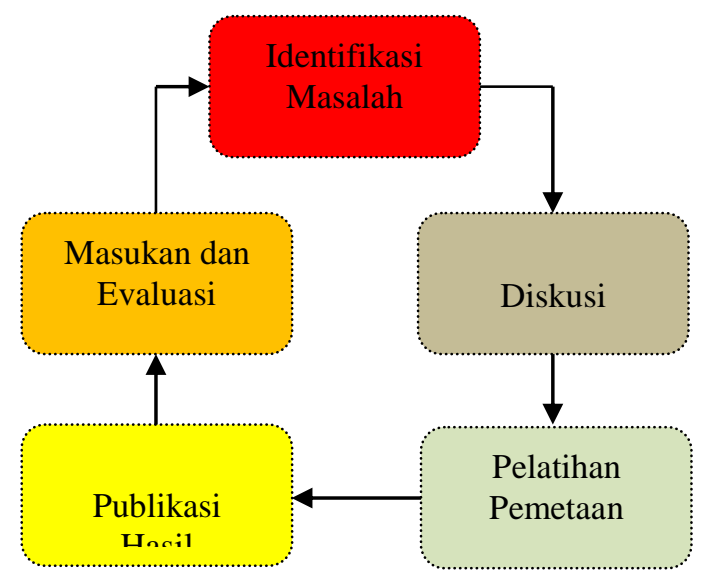

Gambar 1. Alur Langkah Pelaksanaan

Pelatihan dilaksanakan di Balai Desa Kembaran Kecamatan Kembaran Kabupaten Banyumas. Metode yang digunakan dalam kegiatan pelatihan adalah ceramah, diskusi dan praktek aplikasi pembuatan peta dengan SIG menggunakan software Arcview. Perangkat desa diajak untuk melakukan refleksi fasilitas peta yang ada di Kelurahan termasuk kesulitan dan kendala yang dihadapi perangkat desa dalam membuat peta yang benar.Penyampaian materi peta dikombinasi dengan diskusi, dilajutkan dengan praktek membuat peta administrasi dan penggunaan lahan Kelurahan Kembaran Kecamatan Kembaran Kabupaten Banyumas dengan aplikasi SIG. Disamping itu perangkat desa juga diajarkan cara mengaplikasikan GPS, karena peta yang dihasilkan dari pelatihan ini merupakan peta administrasi desa dengan penentuan batas dilakukan dengan memanfaatkan teknologi survey GPS dan data penginderaan jauh resolusi tinggi.

\section{HASIL DAN PEMBAHASAN}

Pelatihan dilaksanakan di Balai Desa Kembaran Kecamatan Kembaran Kabupaten Banyumas. Perangkat desa diajak untuk melakukan refleksi fasilitas peta yang ada di Kelurahan termasuk kesulitan dan kendala yang dihadapi perangkat desa dalam membuat peta yang 
benar. Relatif banyak terkait dengan pengetahuan terhadap pembuatan peta, termasuk masih belum dipahaminya simbol-simbol dalam peta serta minimnya ketersediaan fasilitas peta yang terdapat di kelurahan seperti peta administrasi dan peta penggunaan lahan. Hal tersebut menujukkan pengetahuan, kapasitas dan keterampilan aparatur desa dalam pemetaan digital dengan memanfaatkan teknologi Sistem Informasi Geografis (SIG) masih kurang. Sesuai dengan perkembangan jaman seharusnya aparatur atau perangkat desa harus memiliki pengetahuan dan skill pemetaan yang memadai sehingga memudahkan di dalam pelayanan informasi yang dibutuhkan masyarakat. Kemudahan teknologi komputer saat ini memberikan implikasi pada perkembangan teknologi pemetaan dan Sistem Informasi Geografis.Kemudahan dalam melakukan modifikasi dan manipulasi dalam analisis di lingkungan Sistem Informasi Geografis tentu saja memberikan keuntungan khususnya bagi para pengguna termasuk pemerintah untuk melihat ruang dan secara praktis melakukan analisis terhadap kebutuhan pengguna dan masyarakat.

Beberapa literatur menyebutkan secara garis besar Sistem Informasi Geografis (SIG) sebagai suatu cara atau prosedur yang menggunakan komputer untuk memperoleh, memeriksa, menghimpun, menyimpan, mengolah dan mempertukarkan data, menampilkan kembali dan memanipulasi data yang berbasis geografi (Aronoff, 1989).

selanjutnya pemberian materi secara klasikal terkait oengertian dasar peta dan Sistem Informasi Geografis (SIG), meliputi sejarah dan pengertian peta, kegunaan peta, komponenkomponen/kelengkapan peta, Sistem Informasi Geografis (SIG), data raster dan vektor, sumber informasi geografi (peta analog, data dari penginderaan jauh, data hasil pengukuran lapangan, data GPS/Global Positioning System), tujuan adanya Sistem Informasi Geografis (SIG), Manfaat Sistem Informasi Geografis (SIG), Penyajian data Sistem Informasi Geografis (SIG), analsisis keruangan sesuai data yang digunakan. Seperti yang dijelaskan Prahasta (2000) di dalam SIG terdapat beberapa model data diantaranya adalah :

\section{Model data vektor.}

Model data vektor terdiri dari titik-titik yang membentuk objek geometrik sederhana seperti titik, garis, dan area. Dalam banyak literatur, objek titik sering juga disebut dengan node, vertex, dan 0-cell.Unit terkecil model data vektor adalah titik, lalu kemudian objek garis yang tersusun dari dua atau lebih objek titik, sedangkan objek area terdiri dari sejumlah garis yang berhubungan membentuk area.

2. Model data raster.

Model data raster mempunyai struktur data yang tersusun dalam bentuk matriks atau pixel dan membentuk grid.Dalam model data raster setiap lokasi dipresentasikan sebagai suatu posisi sel. Sel ini diorganisasikan dalam bentuk kolom dan baris sel-sel dan biasa disebut sebagai grid satu sel. Setiap barismatrik berisikan sejumlah sel yang me miliki nilai tertentu yang merepresentasikan suatu fenomena geografik.Secara konseptual model data raaster merupakan model data spasial yang paling sederhana.Pada model raster, data spasial diorganisasi dalam sel (grid cells) atau piksel.Piksel adalah unit dasar yang digunakan untuk menyimpan informasi secara eksplisit.Masing -masing piksel mewakili luasan tertentu di permukaan bumi. Pada dasarnya dalam pemodelan raster, permukaan bumi yang dimodelkan menjadi matriks dua dimensi yang terdiri dari sel -sel bumi yang sama besar. Biasanya sebuah sel hanya mengandung satu nilai tertentu.Konsep 
skala pada umumnya dipakai untuk data dengan format vektor.Untuk data raster, tingkat kerincian informasi disebut resolusi.Resolusi diasosiasikan dengan ukuran luasan permukaan bumi yang diwakili oleh satu sel. Suatu data raster dengan resolusi tinggi menggambarkan tingkat kerincian informasi yang tinggi, dimana setiap sel mewakili luasan yang lebih kecil di permukaan bumi.Untuk aplikasi yang membutuhkan akurasi yang tinggi, peta dengan skala besar dan nilai pixel yang kecil lebih tepat untuk digunakan (Ekadinata dkk, 2008).

Setelah secara teori disampaikan pengertian dasar peta dan Sistem Informasi Geografis (SIG) dilanjutkan diberikan materi tentang aplikasi pemetaan digital dengan memanfaatkan teknologi Sistem Informasi Geografis dengan cara menjelaskan langkah-langkah di dalam pengaplikasiannya. Dengan menggunakan software Arc View 3.3.

Selanjutnya dilakukan praktek langsung, pembuatan peta administrasi dan penggunaan lahan Desa Kembaran. Peserta praktek yaituperangkat Desa Kembaran yang telah ditetapkan oleh Kepala Desa berjumlah 7 orang, karena keterbatasan fasilitas komputer yang ada di Kantor Desa. Namun seluruh perangkat desa mengikuti jalanya praktek.

Yang pertama dilakukan adalah georefencing yaitu menentukan titik ikat untuk menentukan dan mengetahui koordinat suatu tempat atau wilayah. Dalam menentukan titik ikat bisa digunakan koordinat geografis ataupun UTM (Universal Tranverse Mercator) dalam hal ini digunakan koordinat geografis. Selanjutnya dilakukan digitasi yaitu untuk mendigitasi batas wilayah Desa Kembaran meliputi batas administrasi (batas kecamatan, batas desa), jalan dan sungai sekaligus bangunan seperti kantor desa, sekolah, kantor kecamatan, pasar kantor polisi dan lain-lain. Bersamaan dengan digitasi batas administrasi juga dilakukan digitasi penggunaan lahan seperti sawah, pekarangan, pemukiman. Digitasi dilakukan menggunakan Citra satelit Kelurahan Kembaran beresolusi tinggi sebagai peta dasar.

Penataan atribut dilakukan setelah digitasi selesai. pemberian nama atribut disesuaikan dengan atribut apa yang akan dilakukan penataan dan pemberian nama, misalnya batas kecamatan, batas desa, jalan atau sungai. Sekaligus dilakukan labeling peta seperti pemberian nama desa, penggunaan lahan dan lain-lain

Langkah terakhir adalah lay out, mentukan ukuran kertas yang akan digunakan, pemberian grid dan pengaturan grid sesuai dengan yang diperlukan dan disesuaikan intervalnya. Dalam lay out ini memuat judul peta, skala untuk mengetahui perbandingan/rasio jarak di peta dengan jarak sesungguhnya dipermukaan bumi. Legenda untuk memberikan kemudahan kepada pembaca untuk mengetahui simbol yang terdapat di peta. Insert untuk mengetahui posisi atau letak suatu wilayh dalam wilayah tertentu, misalnya suatu desa tertentu berada diposisi mana dalam suatu kecamatan atau kecatan terletak dibagian mana dari suatu kabupaten. Sumber peta menjelaskan sumber yang digunakan dalam pembuatan peta atau peta daasar yang digunakan. Kemudian orientasi arah mata angin untuk memudahkan mengetahui arah dalam peta yang dibuat.

Guna mempercepat transfer teknologi pembuatan peta, peserta selalu didampingi oleh tim pelaksana, sehingga ketika menemui kesulitan langsung bisa bertanya dan diberikan penjelasan serta pengarahan sehingga kesulitan segera bisa diatasi dan peserta tidak bingung. 
Dhi Bramasta, Anang Widhi Nirwansyah

Disamping itu perangkat desa juga diajarkan cara megaplikasikan GPS, karena peta yang dihasilkan dari pelatihan ini merupakan peta administrasi desa dengan penentuan batas dilakukan dengan memanfaatkan teknologi survey GPS dan data penginderaan jauh resolusi tinggi.

Hasil pelaksanaan program pengabdian masyarakat telah berhasil mencapai target dan luaran yang telah ditetapkan yaitu peningkatan kapasistas dan keterampilan aparatur atau perangkat desa dalam skill pembuatan peta. Hal ini ditunjukkan denganmeningkatnya pengetahuan peserta mengenai peta serta luaran yang dihasilkan peserta yaitu peta administrasi dan penggunaan lahan Desa Kembaran Kecamatan Kembaran Kabupaten Banyumas. Selanjutnya modul yang berisi tentang tutorial atau langkahlangkah dalam pembuatan yang sebelumnya dipersiapkan oleh tim diberikan kepada peserta, karena aplikasi pembuatan peta terdapat langkah-langkah yang sangat banyak sekali sehingga sangat memungkinkan peserta lupa. Dengan adanya modul tersebut memberikan solusi bagi peserta jika terjadi kelupaan.

\section{SIMPULAN}

Pelatihan pembuatan peta guna peningkatan kapasitas dan keterampilan perangkat desa di Kelurahan Kembaran Kecamatan Kembaran Kabupaten Banyumas dapat meningkatkan kapasitas dan keterampilan aparatur atau perangkat desa dalam pembuatan peta mulai dari kegunaan, fungsi peta sampai dengan pembuatan peta dengan pemanfaatan teknologi digital Sistem Informasi Geografis sesuai dengan kaidah kartografi yang benar sehingga pelatihan yang diselenggarakan bagi aparatur atau perangkat desa akan sangat membantu dalam implementasi prosespembuatan peta dan penyediaan informasi bagi masyarakat.
Luaran yang dihasilkan adalah peta administrasi dan penggunaan lahan Desa Kembaran Kecamatan Kembaran Kabupaten Banyumas.

\section{DAFTAR PUSTAKA}

Aronoff, S. (1989). Geographic Information System: A. Management Perspective. Canada : WDL Publications, Ottawa.

Bramasta, D., (2014). Proses Keruangan Pelestarian Saujana Budaya Kota (Urban Heritage)Di Kecamatan Laweyan Kota Surakarta Tahun 2013. Thesis. PKLH : Pendidikan GeografiUniversitas Sebelas Maret : Surakarta.

Ekadinata, A, Dewi. S, Hadi. D.P, Nugroho. D.K,Johana F. (2008), Sistem informasi geografiss danPenginderaan Jauh Menggunakan ILWIS Open Source. Bogor : World Agroforestry Center:

Nirwansyah, A. W.(2012a). Damage exposure Estimation Due to Coastal Flood and SeaLevel Rise In Pekalongan Municipal Using Participatory GIS Method To Support Spatial Planning. Thesis. Fakultas Geografi. Universitas Gadjah Mada.

Nirwansyah, A. W.(2012b). MangroveCommunity Contribution On Disaster RiskReduction Due To Coastal Flood (A Case Study In Lawangrejo Village, Pemalang Regency), Proceeding of Ecosystem Based Disaster Risk Reduction. JSP of Center for Natural Resource Development (CNRD). Universitas Gadjah Mada. Yogyakarta 3-6 December 2012.

Prahasta. E, (2000), Model Permukaan Digital, Bandung : Penerbit Informatika 